\title{
COMPARATIVE EFFECT OF C3a AND C5a ON ADHESION MOLECULE EXPRESSION ON NEUTROPHILS AND ENDOTHELIAL CELLS
}

\author{
K. E. FOREMAN, ${ }^{1,2}$ M. M. GLOVSKY, ${ }^{3}$ R. L. WARNER, ${ }^{1}$ \\ S. J. HORVATH, ${ }^{4}$ and P. A. WARD ${ }^{1}$ \\ ${ }^{\mathrm{I}}$ University of Michigan, \\ Department of Pathology, \\ Ann Arbor, Michigan \\ ${ }^{2}$ Parke-Davis Research \\ Division of Warner-Lambert Company, \\ Ann Arbor, Michigan \\ ${ }^{3}$ Huntington Memorial Hospital, \\ Asthma and Allergy Center, \\ Pasadena, California \\ ${ }^{4}$ Caltech \\ Beckman Institute, Pasadena, California
}

\begin{abstract}
Complement activation is known to enhance neutrophil binding to human umbilical vein endothelial cells (HUVECs). Recently, we have shown that recombinant human C5a upregulates P-selectin in HUVECs. Unstimulated human neutrophil binding is also increased on C5a stimulated HUVECs. We demonstrate in this report that $\mathrm{C} 5 \mathrm{a}$ upregulates $\mathrm{CD} 1 \mathrm{1b} / \mathrm{CD} 18$ in human neutrophils. Also shown is that synthetic $\mathrm{C} \mathrm{a}_{57-77}$ and an analog 15 amino acid $\mathrm{C} 3$ a peptide $\left(\mathrm{C}_{3} \mathrm{a}_{15}\right)$ neither upregulate CD1 b/CD18 nor do the C3a peptides increase P-selectin, ICAM-1 or E-selectin in HUVECs. Thus C5a and not C3a is responsible for early ( $\sim 30$ minutes) neutrophil adhesion to endothelial cells after complement activation.
\end{abstract}

\section{INTRODUCTION}

The human complement derived anaphylatoxins C3a and C5a are structurally related peptides released from the $\alpha$-chain of $\mathrm{C} 3$ and C5 during complement activation via the classical or the alternative pathway (1). These multifunctional peptides have been shown to possess similar biological activities and effect a wide variety of cells and tissues involved in acute inflammation. Among their 
numerous biological effects, both $\mathrm{C} 3 \mathrm{a}$ and $\mathrm{C} 5 \mathrm{a}$ induce neutrophil aggregation, lysosomal enzyme release from human neutrophils and increase vascular permeability to the skin (2). C5a is also chemotactic for neutrophils in human skin and enhances neutrophil accumulation in lung vessels. It is known that C5a is approximately 100 -fold more active in most assay systems than C3a (2). However, the plasma concentration of $\mathrm{C} 3 \mathrm{a}$ is 15 -fold greater than that of C5a (70 $\mu \mathrm{g} / \mathrm{ml}$ compared with $4.9 \mu \mathrm{g} / \mathrm{ml}$ ), and this higher concentration may help compensate for the lower functional activity of C3a (2).

Recent studies from our laboratory and others have indicated that complement cleavage products, including C5a, may be involved in leukocyte adhesion to endothelial cells, a process which is recognized as one of the first critical steps in neutrophil migration into an area of inflammation. In vitro studies have demonstrated C5a upregulation of CD11b/CD18 receptor expression on neutrophils (3-5). C5a upregulates P-selectin expression on human umbilical vein endothelial cells (HUVECs) resulting in increase adhesion of unstimulated neutrophils to the endothelial cells (6). Deposition of sublytic concentrations of C5b-C9 (membrane attack complex) and also been shown to upregulate endothelial cell P-selectin expression resulting in neutrophil adhesion $(7, \mathrm{~K}$. S. Kilgore personal communication). The studies presented here were designed to compare the effect of $\mathrm{C} 3 \mathrm{a}$ and $\mathrm{C} 5 \mathrm{a}$ on both endothelial cell and neutrophil adhesion molecule expression.

\section{METHODS}

Chemicals and Reagents. Recombinant human C5a was a gift of Dr. Henry Showell (Pfizer Central Research, Groton, Connectuicut). The ED50 for the chemotactic activity of this C5a preparation was 1-5 $\mathrm{nM}(6)$. The $\mathrm{C} 3$ a peptides, $\mathrm{C} 3 \mathrm{a}_{57-77}$, as potent as native $\mathrm{C} 3 \mathrm{a}(8)$, and $\mathrm{C} 3 \mathrm{a}_{15}$ an analogue peptide with the structure Trp-Trp-Gly-Lys-Lys-Tyr-Arg-Ala-Ser-Lys-Leu-Gly-Leu-AlaArg was found to be 12-15 times more potent than native $\mathrm{C} 3 \mathrm{a}$ (9). $\mathrm{C} 3 \mathrm{a}_{15}$ has been altered with the italicized amino acids from the native $\mathrm{C}_{3} \mathrm{a}_{63-77}$. Both were synthesized by solid phase automated chemistry (Applied Biosystems) and were purified by HPLC or by Sephadex chromatography. Structures of the $\mathrm{C} 3$ a peptides were confirmed by amino acid analysis. Functional activity of the peptides was demonstrated by a $>700 \%$ increase in permeability of radioiodinated BSA into rat skin injected intradermally with the $\mathrm{C} 3$ a peptides. Murine monoclonal antibody against human P-selectin (PNB1.6) was the gift of Dr. James C. Paulson (Cytel Corporation, San Diego, California). Monoclonal antibody to human CD18 was provided by Dr. C. Wayne Smith (Baylor University, Houston, Texas). The human anti-E-selectin monoclonal antibody (CL3) has been previously described (10). Anti-ICAM-1 antibody was obtained from Research and Diagnostic Systems (Minneapolis, Minnesota). Recombinant human TNF $\alpha$ was obtained from Peprotech (Rocky Hill, New Jersey). The 2', 7'-bis-(2-carboxyethyl)-5 (and -6) -carboxyfluorescein, acetoxymethyl (BCECFAM) used for fluorescent labeling of neutrophils was purchased from Molecular Probes (Eugene, Oregon). Other reagents were obtained from Sigma (St. Louis, Missouri).

Endothelial Cell Preparation. HUVECs were isolated by collagenase treatment of freshly 
obtained human umbilical cords and plated on gelatin-coated tissue culture dishes (Falcon Co., Lincoln Park, New Jersey) (11). Dulbecco's modified Eagle's media with Ham's F-12 and 20\% heat inactivated fetal bovine serum (FBS) supplemented with $2 \mathrm{mM} \mathrm{L}$-glutamine, 100 units $/ \mathrm{ml}$ penicillin, $100 \mu \mathrm{g} / \mathrm{ml}$ streptomycin, $0.25 \mu \mathrm{g} / \mathrm{ml}$ Fungizone, $25 \mu \mathrm{g} / \mathrm{ml}$ endothelial cell growth supplement (Collaborative Research, Bedford, Massachusetts), and 15 units $/ \mathrm{ml}$ bovine heparin was used to maintain the cells. HUVECs were used between the first and third passage and were characterized by a cobblestone appearance and specific staining for von Willebrand factor.

Preparation of Neutrophils. Whole blood was obtained from healthy human volunteers and anticoagulated with citrate dextrose solution. Neutrophils were isolated by gradient centrifugation over Ficoll-Hypaque (Pharmacia, Uppsala, Sweden) followed by $1 \%$ dextran sedimentation for 1 $\mathrm{hr}$ to separate neutrophils from erythrocytes. Remaining erythrocytes were removed by hypotonic lysis and the neutrophils washed twice in Hanks' balance salt solution containing $0.1 \%$ bovine serum albumin (HBSS-BSA). Cells were resuspended to $5 \times 10^{6}$ cells $/ \mathrm{ml}$ in HBSS-BSA and preparations contained $>95 \%$ neutrophils.

Fluorescent Labeling of Neutrophils. Fifty $\mu \mathrm{g}$ aliquots of BCECF-AM were freshly dissolved in $50 \mu \mathrm{l}$ dimethyl sulfoxide. This was added to the neutrophil suspension at a final concentration of $1 \mathrm{mM} \mathrm{BCECF-AM}$. The mixture was incubated for $30 \mathrm{~min}$ at $37^{\circ} \mathrm{C}$, and then the cells were washed twice with $4^{\circ} \mathrm{C}$ HBSS-BSA. The cells were resuspended in HUVEC media at $1 \times$ $10^{6} \mathrm{cells} / \mathrm{ml}$ for use in the adhesion assay.

Assay of Neutrophil Adherence to HUVEC Monolayers. An assay for measuring static adhesion of fluorescent labeled neutrophils to HUVEC monolayers has been recently described (12). Briefly, HUVECs were plated at $5 \times 10^{4}$ cells/well in 96-well flat-bottom fibronectin-coated plates and grown to confluence at $37^{\circ} \mathrm{C}$ with $5 \% \mathrm{CO}_{2}$. The cells were washed twice with fresh HUVEC media and stimulated as described in the text at $37^{\circ} \mathrm{C}$ with $5 \% \mathrm{CO}_{2}$. The cells were washed twice with warm media and $1 \times 10^{5}$ fluorescent-labeled neutrophils added to each well. A standard curve relating cell number to fluorescence was prepared on each plate by performing two fold serial dilution of the neutrophils from $1 \times 10^{5}$ to $6.25 \times 10^{3}$ cells/well. Microtiter plates were incubated $30 \mathrm{~min}$ at $37^{\circ} \mathrm{C}$ with $5 \% \mathrm{CO}_{2}$. The non-adherent neutrophils were then removed with gentle washing. Remaining fluorescence was measured with a Cytofluor 2300 Fluorescence Measurement System (Millipore, Bedford, Massachusetts) using an excitation filter at $485 \mathrm{~nm}$ and emission filter at 530 $\mathrm{nM}$.

ELISA for Adhesion Molecule Expression. An ELISA to determine adhesion molecule expression on endothelial cells was developed in this laboratory (13). Briefly, HUVECs were plated at $5 \times 10^{4}$ cells/wells in 96-well flat-bottom fibronectin-coated plates and grown to confluence at $37^{\circ} \mathrm{C}$ with $5 \% \mathrm{CO}_{2}$. The cells were washed with warm HUVEC media and stimulated as described in the text at $37^{\circ} \mathrm{C}$. Following stimulation, the endothelial cell monolayers were washed and fixed with $1 \%$ paraformaldehyde. $5 \%$ non-fat dry milk was used to reduce nonspecific binding and the cells incubated with primary antibody $(1 \mu \mathrm{g} / \mathrm{ml})$ for $45 \mathrm{~min}$. The cells were washed and a peroxidaseconjugated rabbit anti-mouse IgG (Dako Corporation, Carpinteria, California) was added for 40 min. After washing, the substrate ( $o$-phenylenediamine dihydrochloride) was added for $30 \mathrm{~min}$ and the reaction quenched with $3 \mathrm{M}$ sulfuric acid. Optical density was determined at $490 \mathrm{~nm}$ using an automated microplate reader (EL340, Bio-Tek Instruments, Winooski, Vermont).

Flow Cytometry for Adhesion Molecule Expression. Rat and human peripheral neutrophils were analyzed for a change in expression of CD11b and CD18 surface molecules by immunofluorescence flow cytometry. Purified neutrophils were stimulated for $15 \mathrm{~min}$ at room temperature with either C5a or C3a, and PMA was used as a positive control with unstimulated cells as a negative control. Cells were then washed and stained with murine monoclonal antibodies specific for the desired adhesion molecules (for rat neutrophils: IB6c, CD1 1b; WT-1, CD18; for human neutrophils: mAB17, CD11b; CL-26, CD18), followed by phyocerythrin labeled anti-mouse IgG as the secondary antibody (AMAC, Inc., Westland, Maine). The isotype matched control consisted of cells 
stained with MOPC-21 (mouse IgG) and phyocerythrin labeled secondary antibody. Monoclonal antibody binding of gated neutrophil populations (identified by forward vs. right angle scatter characteristics) were measured on a FACScan Flow Cytometry System (Becton Dickinson, San Jose, California) in which 10,000 cells per determination were counted and the extent of binding was analyzed using PC-LYSYS software (Becton Dickinson).

Statistical Analysis. Each ELISA and cell adhesion assay experiment contained 4-6 replicates and was repeated 2-3 times with similar results. Each datapoint represents the mean from a representative experiment \pm the standard error of the mean. Statistical differences between groups were measured by analysis of variance.

\section{RESULTS}

Roles of C5a and C3a Peptides in Endothelial Cell Adhesion Molecule Expression. As the C3a peptides, $\mathrm{C}_{3} \mathrm{a}_{57-77}$ and $\mathrm{C} 3 \mathrm{a}_{15}$, have been shown to be as or more active than native $\mathrm{C} \mathrm{a}_{1-77}$ in biological systems (9), we studied their effect on adhesion molecule expression on HUVECs. HUVECs were incubated for $2 \mathrm{hr}$ (for detection of E-selectin and ICAM-1) or $10 \mathrm{~min}$ (for detection of P-selectin) with $50 \mu \mathrm{M} \mathrm{C} \mathrm{a}_{55-77}, 50 \mu \mathrm{M} \mathrm{C} 3 \mathrm{a}_{15}$, or $250 \mathrm{nM} \mathrm{C5a}$. Twenty-five $\mathrm{ng} / \mathrm{ml} \mathrm{TNF} \alpha$ or $5 \mathrm{mM}$ histamine was used as a positive control and HUVEC media was used for a negative control. The results demonstrated the expected increase in E-selectin and ICAM-1 expression with TNF $\alpha$ stimulation; however, there was no increase in expression of either adhesion molecule on HUVECs incubated with $\mathrm{C}_{3} \mathrm{a}_{57-77}$ or $\mathrm{C}_{3} \mathrm{a}_{15}$ (Table 1). Stimulation of the cells with 250 $\mathrm{nM}$ C5a or $5 \mathrm{mM}$ histamine resulted in the expected upregulation of P-selectin in the endothelial cells while $\mathrm{C}_{3} \mathrm{a}_{57-77}$ and $\mathrm{C}_{3} \mathrm{a}_{15}$ did not result in expression above basal levels (Table 1).

Table 1. Adhesion Molecule Expression on HUVECs ${ }^{a}$

\begin{tabular}{lccc}
\hline \multirow{2}{*}{$\begin{array}{c}\text { Stimulus } \\
\text { added }\end{array}$} & \multicolumn{3}{c}{ Adhesion molecule expression (optical density at $490 \mathrm{~nm}$ ) } \\
\cline { 2 - 4 } & E-selectin & ICAM-1 & P-selectin \\
\hline None & $0.614 \pm 0.018$ & $1.447 \pm 0.017$ & $0.749 \pm 0.011$ \\
$\mathrm{TNF} \alpha$ & $2.174 \pm 0.064^{b}$ & $2.431 \pm 0.025^{b}$ & $0.734 \pm 0.003$ \\
$\mathrm{Histamine}$ & $0.625 \pm 0.014$ & $1.435 \pm 0.029$ & $0.851 \pm 0.026^{b}$ \\
$\mathrm{C5a}$ & $0.608 \pm 0.016$ & $1.447 \pm 0.031$ & $0.816 \pm 0.012^{b}$ \\
$\mathrm{C3a}_{15}$ & $0.604 \pm 0.019$ & $1.477 \pm 0.020$ & $0.721 \pm 0.020$ \\
$\mathrm{C}_{57-77}$ & $0.604 \pm 0.031$ & $1.459 \pm 0.045$ & $0.732 \pm 0.024$ \\
\hline
\end{tabular}

a $5 \times 10^{4}$ HUVECs were incubated with indicated stimulus for 2 hours (E-selectin and ICAM-1 expression) or 10 minutes (P-selectin expression) with TNF $(25 \mathrm{ng} / \mathrm{ml})$, histamine $(5 \mathrm{mM})$, C5a $(250 \mathrm{nM}), \mathrm{C}^{2} \mathrm{a}_{15}(100 \mu \mathrm{g} / \mathrm{ml})$ or $\mathrm{C} \mathrm{a}_{57-77}(100 \mu \mathrm{g} / \mathrm{ml})$. Adhesion molecule expression was determined using a cell-based ELISA assay as described.

${ }^{b} p$-value $<0.05$ as compared to absence of stimulus. 


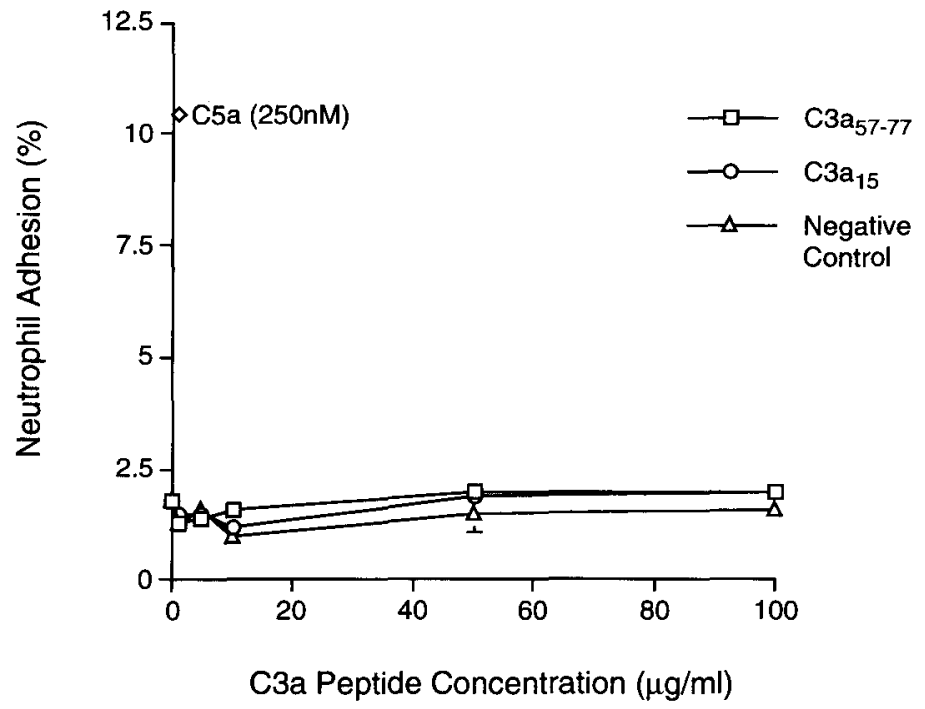

Fig. 1. Neutrophil binding to HUVECs incubated for 10 minutes at $37^{\circ}$ with $1-100 \mu \mathrm{g} / \mathrm{ml}$ $\mathrm{C} \mathrm{a}_{57-77}$ or $\mathrm{C}_{3} \mathrm{a}_{15}$ was not increased over background levels. However, incubation of the endothelial cells with $250 \mathrm{nM}$ C5a did increase neutrophil binding 6-fold above baseline levels.

Effects of C3a and C5a Treatment of HUVECs on Neutrophil Adherence. Endothelial cells were incubated with a $1-100 \mu \mathrm{g} / \mathrm{ml}(0.5-50 \mu \mathrm{M})$ $\mathrm{C} 3 \mathrm{a}_{57-77}$ and $\mathrm{C}_{3} \mathrm{a}_{15}$ for $10 \mathrm{~min}$. The HUVECS were then washed and fluorescently labeled neutrophils added. No difference in neutrophil binding to the endothelial cells was seen with C3a stimulated HUVECs as compared to unstimulated controls (Fig. 1). In contrast, incubation of the HUVECs with 250 $\mathrm{nM} \mathrm{C5a}$ for $10 \mathrm{~min}$ resulted in a six-fold increase in neutrophil adherence, as expected.

CD11b/CD18 Receptor Expression on Neutrophils Incubated with C5a and C3a Peptides. Incubation of $\mathrm{C}^{3} \mathrm{a}_{15}$ or $\mathrm{C} \mathrm{a}_{57-77}(50 \mu \mathrm{g} / \mathrm{ml})$ with human neutrophils for 15 min showed no significant upregulation of either CD11b or CD18 as measured by flow cytometry. However, incubation of the neutrophils with either C5a $(250 \mathrm{nM})$ or PMA $(100 \mathrm{ng} / \mathrm{ml})$ upregulated both CD11b and CD18 (Table 2).

\section{DISCUSSION}

Previous studies from our laboratory and others indicate complement may play an important role in neutrophil migration into areas of inflammation. Using 
Table 2. CD11b and CD18 Expression on Neutrophils ${ }^{a}$

\begin{tabular}{lcr}
\hline \multirow{2}{*}{$\begin{array}{l}\text { Stimulus } \\
\text { added }\end{array}$} & \multicolumn{2}{c}{ Percent increase in expression } \\
\cline { 2 - 3 } & CD11b & CD18 \\
\hline PMA & $195 \%$ & $156 \%$ \\
C5a & $134 \%$ & $145 \%$ \\
C3a & $-20 \%$ & $-27 \%$ \\
$\mathrm{C}_{15} \mathrm{a}_{57-77}$ & $-28 \%$ & $-16 \%$ \\
\hline
\end{tabular}

${ }^{a}$ Neutrophils were incubated for 15 minutes at room temperature with PMA $(100 \mathrm{ng} / \mathrm{ml})$, C5a $(250 \mathrm{nM})$, or $\mathrm{C}^{2} \mathrm{a}_{15}(50 \mu \mathrm{g} / \mathrm{ml})$ or $\mathrm{C}_{3} \mathrm{a}_{57-77}(50 \mu \mathrm{g} / \mathrm{ml})$. CD11b and CD18 expression were determined using flow cytometry as described. Results are expressed as percent increase over baseline levels of expression. Negative results indicate a decrease in mean standard fluorescence.

a hybrid molecule of the complement activator cobra venom factor linked to the endothelial binding lectin Ulex europaeus 1 (ULEX-CVF), Marks et al. demonstrated that in the presence of serum, ULEX-CVF rapidly activated complement resulting in complement fixation on the endothelial cell surface (14). Under the experimental conditions, $\mathrm{iC} 3 \mathrm{~b}, \mathrm{C} 5$ and membrane attack complex were deposited on the cells, and the complement fixation resulted in rapid and potent adhesion of unstimulated neutrophils to the endothelial cells. This adhesion was mediated by the iC $3 b$ receptor $(\mathrm{CD} 11 \mathrm{~b} / \mathrm{CD} 18, \mathrm{CR} 3)$ as anti-CD11b or CD18 antibodies inhibited neutrophil binding to the endothelium by $65-89 \%$, and $\mathrm{C} 3$ deposition was demonstrated to be critical for the observed increase in adhesion (14).

Involvement of the C5a in adhesion molecule expression and function has been demonstrated. Using recombinant $\mathrm{C} 5 \mathrm{a}$, we have previously demonstrated that C5a upregulated P-selectin in a time and dose-dependent manner (16). This increase in P-selectin expression was accompanied by a rapid increase in adherence of unstimulated neutrophils to the stimulated endothelial cells (6). Maximal neutrophil binding peaks at 10 min and returns to baseline at 30 min which coincides with the time course of P-selectin expression. C5a did not increase E-selectin expression on the endothelial cells when the incubation with $250 \mathrm{nM}$ $\mathrm{C} 5 \mathrm{a}$ was increased to $2 \mathrm{hr}(6)$. In the present study, C3a peptides, $\mathrm{C}_{3} \mathrm{a}_{57-77}$ and $\mathrm{C}^{2} \mathrm{a}_{15}$ neither upregulated P-selectin, E-selectin, or ICAM-1 (Table 1), nor increased neutrophil binding to HUVECs (Figure 1). The results indicate that C3a does not play a direct role in upregulation of endothelial cell P-selectin; however, C3a and C5a are known to induce histamine release (15) which is known to upregulate P-selectin on endothelial cells. Therefore, C3a may have an indirect effect on P-selectin expression. 
The importance of complement and adhesion molecule expression has also been demonstrated in vivo. Intravenous injection of cobra venom factor into rats results in the development of acute lung injury which is neutrophil dependent and oxygen radical mediated. The injury in this model is measured by increases in lung vascular permeability as measured by leakage of radioiodinated BSA and chromium-labeled red blood cells into the lungs. Monoclonal antibodies directed against CD11b, CD18, ICAM 1, or P-selectin protect the lungs from damage by decreasing the permeability index $51-69 \%$ and the hemorrhage index $48-75 \%(16-18)$. Similar reductions in the neutrophil content of the lungs as measured by myeloperoxidase content were also found.

Adherence of neutrophils to endothelial cells is an essential step in migration of these inflammatory cells to the lung and skin. From the experimental evidence provided by our laboratory and others, we propose that complement may be an essential component in neutrophil adhesion to endothelial cells (Fig. 2). This evidence indicates that C5a plays a keyrole as this anaphylatoxin has

\begin{tabular}{|c|c|c|}
\hline $\begin{array}{l}\text { PMN Adhesion } \\
\text { Molecule }\end{array}$ & $\begin{array}{c}\text { Complement } \\
\text { Activation Factor }\end{array}$ & $\begin{array}{c}\text { Upregulated } \\
\text { Endothelial Adhesion } \\
\text { Molecule }\end{array}$ \\
\hline
\end{tabular}
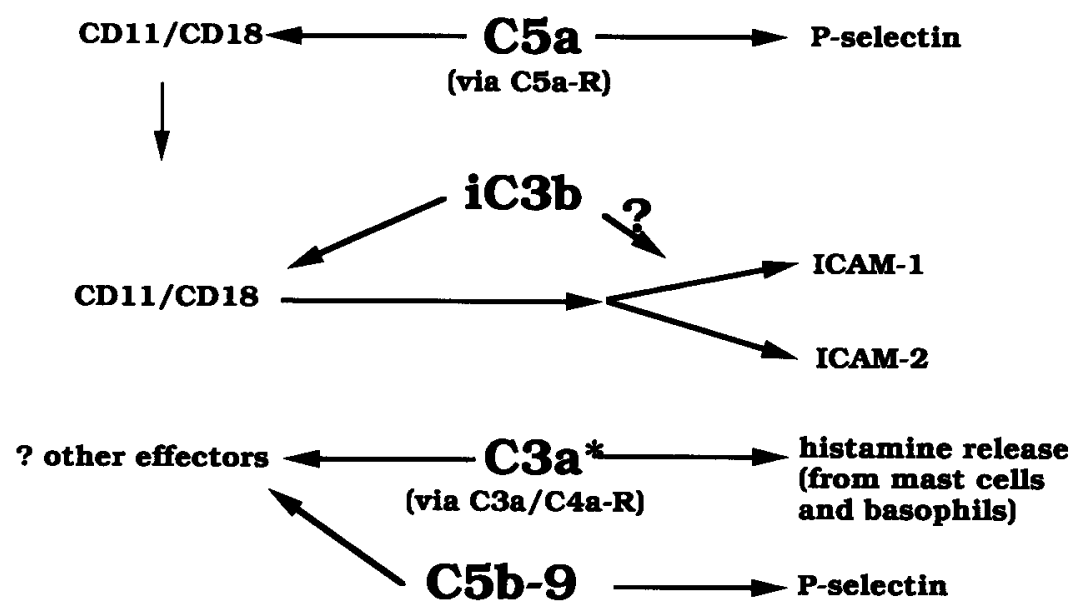

* = No evidence of upregulation of ICAM-1, E-selectin or P-selectin by C3a

Fig. 2. Proposed involvement of complement activation products in the regulation of neutrophil adhesion to endothelial cells. 
been shown to upregulate both neutrophil (CD11b/CD18) and endothelial cell (P-selectin) adhesion-promoting molecules. C3a; however, appears to be of lesser importance, if any, in early neutrophil adherence to endothelium. The membrane attack complex (C5b-C9) in sublytic concentrations is also known to upregulate P-selectin (7). In addition, the deposition of $\mathrm{C} 3 \mathrm{~b}$ and $\mathrm{iC} 3 \mathrm{~b}$ on the endothelial cell surface during complement activation may also enhance neutrophil binding to the endothelial cells.

Acknowledgments-We thank Dr. Henry Showell (Pfizer Central Research, Groton, Connecticut) for supplying recombinant human C5a, Dr. James C. Paulson (Cytel Corporation, San Diego, California) for providing antibodies to human P-selectin, and Dr. C. Wayne Smith (Baylor University, Houston, Texas) for providing antibody to human CD18. We thank Susan Eddy and James Peters for technical assistance in isolation of the endothelial cells. K.E.F. was funded by a fellowship from Parke-Davis Research Division of Warner-Lambert Company. Other support was from NIH Grants HL-31963 and GM-29507.

\section{REFERENCES}

1. Hugli, T. E., and H. J. MüLler-Eberhard. 1978. Anaphylatoxins: C3a and C5a. Adv. Immunol. 261:1-53.

2. Bitter-Suermann, D. 1987. The anaphylatoxins. In The Complement System. Springer-Verlag, Berlin, 367-393.

3. Yancey, K. B., J. O'Shea, T. Chused, E. Brown, T. Takahashi, M. M. Frank, and T. J. LAWLEY. 1985. Human C5a modulates monocyte $\mathrm{Fc}$ and $\mathrm{C} 3$ receptor expression. J. Immunol. 135:465 470.

4. Arnaout, M. A., R. M. Hakin, R. F. Todd, N. Dana, and H. R. Colten. 1985. Increased expression of an adhesion promoting surface glycoprotein in the granulocytopenia of hemodialysis. N. Eng. J. Med. 312:457-462.

5. O'Shea, J. J., E. J. Brown, B. E. Seligmann, J. A. Mètcalf, M. Frank, and J. I. Gallin. 1985. Evidence for distinct intracellular pools of receptors for $\mathrm{C} 3 \mathrm{~b}$ and $\mathrm{C} 3 \mathrm{bi}$ in human neutrophils. J. Immunol. 134:2580-2587.

6. Foreman, K. E., A. A. Vaporciyan, B. K. Bonish, M. L. Jones, K. J. Johnson, M. M. Glovsky, S. M. EDDY, and P. A. WARD. 1994. C5a induced expression of P-selectin in endothelial cells. J. Clin. Invest. 94:1147-1155.

7. Hattori, R., K. K. Hamilton, R. P. McEver, and P. J. Sims. 1989. Complement proteins C5b-C9 induce secretion of high molecular weight multimers or endothelial von Willebrand factor and translocation of granule membrane protein GMP-140 to the cell surface. J. Biol. Chem. 264:9053-9060.

8. Morganroth, M. L., S. O. Schoeneich, G. O. Till, P. A. Ward, S. J. Hovarth, and M. M. GLovsky. 1990. C3a57-77, a C-terminal peptide, causes thromboxane dependent pulmonary vascular constriction in isolated perfused rat lungs. Am. Rev. Respir. Dis. 141:296300 .

9. Ember, J. A., N. L. Johansen, and T. E. Hugli. 1991. Designing synthetic superagonists of C3a anaphylotoxin. Biochemistry (U.S.) 30:3603-3612.

10. Mulligan, M. S., J. Varani, M. K. Dame, C. L. Lane, C. W. Smith, D. C. Anderson, and P. A. WARD. 1991. Role of endothelial-leukocyte adhesion molecule 1 (ELAM-1) in neutrophil-mediated lung injury in rats. J. Clin. Invest. 88:1396-1406. 
11. JAFFE, E. A. Culture and identification of large vessel endothelial cells. In Biology of Endothelial Cells. E. A. Jaffe, editor. Martinus Nijoff, The Hague. 1-13.

12. VAPORCIYAN, A. A., M. L. Jones, and P. A. WARD. 1993. Rapid analysis of leukocyteendothelial adhesion. J. Immunol. Methods 159:93-100.

13. Mulligan, M. S., A. A. Vaporciyan, M. Miyasaka, T. Tamatani, and P. A. Ward. Tumor necrosis factor $\alpha$ regulated in vivo intrapulmonary expression of ICAM-1. Am. J. Path. 142:1739-1749.

14. MARKS, R. M., R. F. TODD, III, and P. A. WARD. 1989. Rapid induction of neutrophilendothelial adhesion by endothelial complement fixation. Nature 339:314-317.

15. Glovsky, M. M., T. E. Hugli, T. Ishizaka, L. M. Lichtenstein, B. W. Erickson. 1979. Anaphylatoxin-induced histamine release with human leukocytes: Studies of C3a leukocyte binding and histamine release. J. Clin. Invest. 64:804-811.

16. Mulligan, M. S., C. W. Smith, D. C. Anderson, R. F. Todd, M. Miyasaka, T. Tamatani, T. B. IsSEKUTZ, and P. A. WARD. 1993. Role of leukocyte adhesion molecules in complementinduced lung injury. 150:2401-2406.

17. Mulligan, M. S., J. Varani, J. S. Warren, G. O. Till, C. W. Smith, D. C. Anderson, R. F. TODD, and P. A. WARD. 1992. Role of $\beta 2$ integrins of rat neutrophils in complementand oxygen radical-medicated acute inflammatory injury. $J$. Immunol. 148:1847-1857.

18. Mulligan, M. S., M. J. Polley, R. J. Bayer, M. F. Nunn, J. C. Paulson, and P. A. WARD. 1992. Neutrophil-dependent acute lung injury. Requirement for P-selectin (GMP-140). J. Clin. Invest. 90:160-167. 